
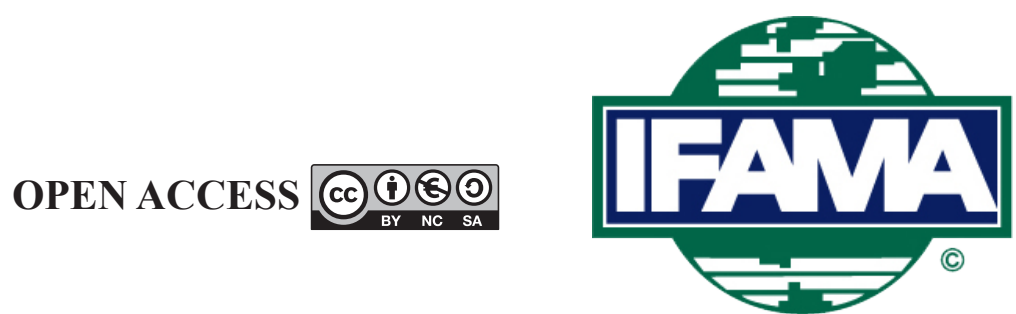

International Food and Agribusiness Management Review

Volume 24, Issue 2, 2021; DOI: 10.22434/IFAMR2020.0013

Received: 21 January 2020 / Accepted: 9 November 2020

\title{
Working conditions and labor flexibility in non-family farms: weather-based labor management by Japanese paddy rice corporations RESEARCH ARTICLE
}

\author{
Hironori Yagi ${ }^{\oplus a}$ and Tsuneo Hayashi ${ }^{b}$ \\ ${ }^{a}$ Associate professor, Department of Agricultural and Resource Economics, \\ University of Tokyo, 1-1-1 Yayoi, Bunkyo, 113-8657 Tokyo, Japan \\ ${ }^{b}$ Senior researcher, Fukui Prefectural Agricultural Experiment \\ Station, Henguri Ryo-machi, Fukui, 918-8215, Japan
}

\begin{abstract}
Improving working conditions in agriculture is of great concern throughout the world. Just as in other industries, many young farm workers prefer to work as salaried employees, which has brought attention to non-family farms as providers of employment opportunities. However, in the presence of a strong need to flexibly respond to weather, there is still difficulty regarding whether workplaces without overworking can exist. This study is based on in-depth surveys of non-family rice farms in Fukui Prefecture, Japan. Our findings suggest that even in non-family farms, holiday-setting is done flexibly to account for weather, and systems that allow for harvesting at appropriate times are in place. During the busy farming period, in joint-stock farms, where multiple farmers invest together, full-time employees work overtime. In contrast, in community farms, many community residents take turns for working, which allows work to be done on time. A closer analysis of work records shows that, in either organizational structure, specific members need to overwork. Reasons behind this include issues with sunk costs in the form of monthly wages, lack of skills among part-time employees, and the communication costs of coordinating with many part-time employees.
\end{abstract}

Keywords: non-family farms, working conditions, labor flexibility, community farming, weather JEL code: J81, L23, M54, Q12

\footnotetext{
(ํ) Corresponding author: youken@g.ecc.u-tokyo.ac.jp
} 


\section{Introduction}

In general, agricultural working conditions across the world are not good and need to be improved. In agriculture, which is affected by weather and biological processes in production, small-scale family farms have the advantage of being able to respond flexibly to these uncertainties. However, this flexibility and working conditions are inextricably linked. Prioritizing the best times to work according to the weather and the plant growth often leads to an abandonment of regular holidays and fixed working hours expected in other industries (e.g. International Labor Organization, 2015). Uncertainty due to weather causes overworking during the busy farming period when time constraints are especially rigid (Kearney et al., 2014; Logstein, 2016). In developed countries, although large machinery is introduced for efficiency optimization, still many farm managers face pressures to expand in scale and reduce costs. Under uncertain weather changes, they are required to maximize operating areas while minimizing fixed costs such as machinery and labor (e.g. De Toro and Hansson, 2004; Sørensen and Bochtis, 2010).

In contrast to family-farm problems of succession failure (De Massis et al., 2008; Gorton and Davidova, 2004; Mann et al., 2013; Suess-Reyes and Fuetsch, 2016), the number of non-family farms has been increasing in recent years (O' Donoghue et al., 2011; Thomson and Davidova, 2014). Instead of starting new businesses as independent farmers, a considerable number of young people choose to work for non-family farms as employees and, thus, non-family farms play an important role in providing job opportunities (Kunitake, 2016). Because non-family farms need to compete with other farms, including family farms, while adhering to compliance requirements for employees, they must be able to execute their work in a flexible as well as occupationally healthy manner. Several empirical studies have addressed the impact of agricultural industrialization on poorer working conditions (Lobao and Stofferahn, 2008). Nonetheless, until now, no research has focused on the relation between working conditions and efficiency in non-family farms and flexible responses to the weather.

This study provides practical insights into improving working conditions in non-family agricultural corporations. As Dyllick and Kai (2002) notes, maintaining decent working conditions is fundamental for sustainable business. Extended studies of family farms address flexibility in their response to weather uncertainties (Allen and Lueck, 1998; Glover and Reay, 2015), accompanying stress (Kearney et al., 2014; Logstein, 2016; Truchot and Andela, 2018), and dependence on seasonal workers (Darpeix et al., 2014). However, the rapid emergence of non-family farm businesses makes it essential to verify their management of concentrated seasonal labor and weather uncertainties.

This study also extends the literature of governance structures (Williamson, 1979, 2005) from the perspective of responding to weather uncertainties in agriculture. Although large open-stock agricultural companies are uncommon globally, small and medium-scale agricultural corporations are widespread and vary widely in organizational features, thereby attracting interest from many scholars (Carney, 2005; Gorton and Davidova, 2004; Grashuis and Su, 2019; Suess-Reyes and Fuetsch, 2016). The scale of paddy farm business, which occupies a central position in arable farming in Japan, has been advancing in recent years (Ministry of Agriculture Forestry and Fisheries, 2015a). Although a sizable number of family farms have expanded in scale, the proportion occupied by non-family farms is relatively large. In particular, a large proportion of non-family farms adopt an organizational form known as a community farm, wherein the residents of the rural community provide capital, land, and labor to these firms. The significance of scrutinizing their sustainability in the agricultural sector should not be understated (Hisano et al., 2018).

Therefore, this paper first clarifies how non-family rice farms implement labor management in response to weather conditions during busy periods and how much overwork is required. Second, it examines the difference in such responses between community farms and other joint-stock farms. To answer these questions, we conducted a case study in the Fukui Prefecture in Japan where paddy cultivation is widespread and the proportion occupied by non-family farms is also large. We clarify the working conditions and the actual working state in different types of non-family farms during the busy farming period. 
The next section examines the theoretical background of managing arable farm workers' responsiveness to weather uncertainty and the organizational form of non-family farms. In the third section, the study areas and data from the case study are introduced. In the fourth section, results are shown for the actual work management and holiday allocation on non-family farms during the busy farming period for these case studies; this section also focus on the mechanism by which overworking is imposed on the employees due to the weather. Finally, we discuss strategies and policies that may be adopted to improve working conditions and work efficiency.

\section{Theoretical background}

\subsection{Labor management to cope with weather uncertainties in arable farming}

Generally, working conditions in the agricultural industry are not favorable; there are few days off (Winter et al., 2016), job satisfaction is low (Lee et al., 2014), and job turnover is high (Fujii et al., 2016). According to a previous survey of farming corporations in Japan, one quarter of farming corporations $(n=291$, of which $41 \%$ are rice farms) replied that the number of days off every month is four or fewer (National Chamber of Agriculture, 2010). In a survey targeting paddy cultivation corporations $(n=419)$, the proportion of corporations providing defined days off for employees was $82.3 \%$, but the proportion of those that did not provide paid leave was $38.7 \%$. This proportion was $83.8 \%(\mathrm{n}=344)$ when combined with those providing fewer than 10 days of paid leave in a year (National Chamber of Agriculture, 2011).

The protection of farm labor is not advancing internationally. For example, although the number of working hours is an important factor for good working conditions (Dumont and Baret, 2017; Gosetti, 2017), International Labor Organization recommendations on the number of working hours are not applicable to the agricultural sector (International Labor Organization, 2014). Similarly, in countries such as the US (Leschak, 2008) and Japan (Kunitake, 2016), the agricultural sector is exempted from working hour regulations. Furthermore, firms comprising family members without non-family employees are exempted from these regulations, and, thus, family farms are exempted from these regulations twice. In the agricultural industry, family members often sacrifice their time to work in response to weather changes, which is also a strength of family farms (Glover and Reay, 2015; Suess-Reyes and Fuetsch, 2016). However, improvements are significant from the perspective of fair international trade and encouraging young people to work in agriculture in the future (Kunitake, 2016; Raynolds, 2014). Consequently, pursuing efficiency without considering the working conditions in non-family farms is inequitable.

Allen and Lueck (1998) empirically examined obstacles confronting non-family arable farms as moral hazard problems and barriers to specialization caused by natural disturbances. The difference between busy and nonbusy periods due to seasonality in arable farming is more significant than other type of operations. According to a survey of farming corporations in Japan, 74\% of rice farm managers recognize the existence of a busy period, compared with only $23.4 \%$ in dairy farming and $16.2 \%$ in the beef cattle industry (National Chamber of Agriculture, 2011). For an arable farmer, it is essential to increase the utilization rate of machinery while adapting to the weather conditions within a limited work period (Astika et al., 1999; Sørensen and Bochtis, 2010). Substantial research has indicated that weather and time constraints are still major concerns for farmers (Kearney et al., 2014; Logstein, 2016; Truchot and Andela, 2018). Previous research also indicates that in paddy cultivation, weather - the most uncertain element in farming - is a significant concern for the operation of machinery (Caicong et al., 2017).

To improve the operating efficiency of machinery, a fixed number of workers need to be secured, according to the number of machines available, on days when machines can be used (e.g. on clear days). On the other hand, days when operation is unfeasible require a flexible response - i.e. making a rainy day an off or reducing the number of workers. For example, fixing weekly offs will result in an inability to catch up with delayed work on rainy days, as shown in Figure 1A. Figure 1B illustrates excess labor on rainy days. Having the ability to respond to weather change is an advantage for flexibility, as shown in Figures 1C and 1D. 


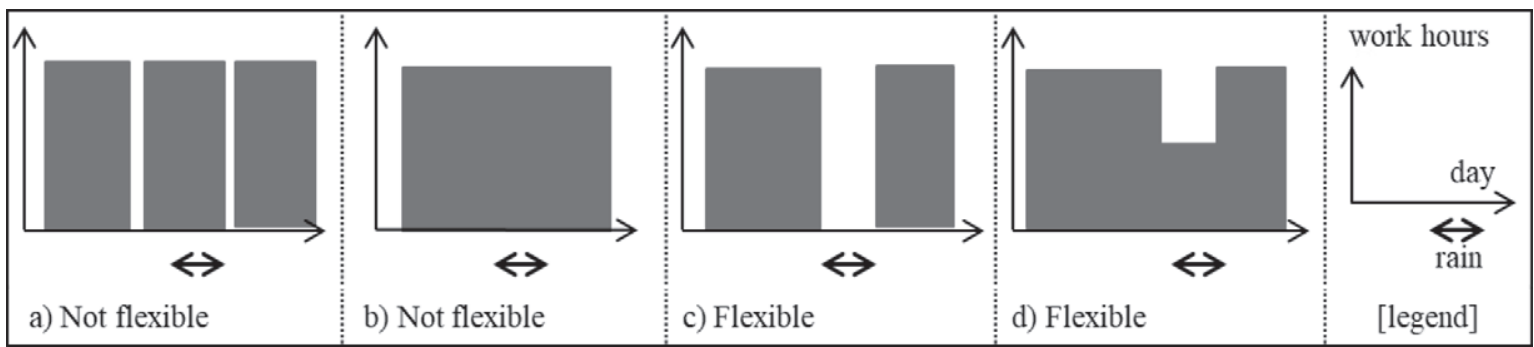

Figure 1. Conceptual drawing of a flexible response to the weather.

Atkinson (1984) discussed the importance of functional flexibility, numerical flexibility, and financial flexibility with regard to labor flexibility to deal with uncertainty. Functional flexibility refers to full-time employees' ability to carry out a variety of tasks through proficiency in different work skills. Numerical flexibility refers to the management's ability to change the number of part-time and outsourced workers, according to work volume. However, the coordination of large temporary workforce increases costs (Kleinknecht et al., 2016). Financial flexibility enables monetary resources for functional and numerical flexibility.

Non-family farms may require employees to overwork to achieve an adequate level of flexibility. Therefore, securing flexibility while avoiding overwork is a salient issue. Overwork during a busy farming season in family farms has been demonstrated by several studies (Glover and Reay, 2015; Kravina et al., 2013; Umemoto, 1992), but research regarding weather uncertainty and flexibility has not been conducted for non-family farms, which is the focus of this study.

\subsection{Organizational forms of non-family farm management}

Williamson (1979) called governance structures 'the institutional matrix within which transactions are negotiated and executed' and identified three types corresponding to transaction costs: market (individuals), hybrid (cooperatives and alliances), and hierarchy (corporations). Uncertainly in labor management renders hierarchical organizations ineffective and forms the basis for family farming (Allen and Lueck, 1998). Non-market influences from communities effectively aggregate farmland as a transaction-specific asset that establishes relations between landlords and farmers (Takahashi, 2012). Hence, community farms - hybrid organizations based on village communities - long have been widespread in Japanese arable farming (Hisano et al., 2018; Yagi and Hayashi, in press). In China, there are three types of leading producer cooperatives: those of local farmers as well as those of governments and firms in related industries (Huang et al., 2016).

There is no unified definition of a family farm (Graeub et al., 2016). In many cases, a family business in general management studies is defined as ownership (capital), labor, and management, or any one of these shouldered by a family (Tagiuri and Davis, 1996). In some definitions, residence near the business area, legal form, and small-scale is also taken into account (European Commission, 2009). In the agricultural sector, it may also be further defined as the degree of inclusion in the market economy, including land ownership by the family and self-sufficiency of the products (European Commission, 2009; Garner and Campos, 2014; Gorton and Davidova, 2004; Whatmore et al., 1987). In this paper, we follow the widely-used definitions by the European Commission (2009) and Ministry of Agriculture Forestry and Fisheries (2015a) and treat ownership (capital) and management by the family, i.e. farms that family members own and manage, as family farms.

As shown in a previous review (Gorton and Davidova, 2004; Suess-Reyes and Fuetsch, 2016), numerous studies have indicated that family businesses are more suitable for farming than non-family firms. It is estimated that in Asia, $99 \%$ of farms and $85 \%$ of the areas under farmed are family farms (Graeub et al., 2016). The coordination of laborers is less of an issue on family farms (Allen and Lueck, 1998; Carter, 1984; Schmitt, 1991), and the ability to adapt to seasonality and multistage production, unique to farming, have 
been cited as reasons for this predominance (Ahn et al., 2012; Allen and Lueck, 1998). On the other hand, non-family farms are more suitable for smoothly transitioning the succession of managerial resources to the next generation (De Massis et al., 2008; Inwood et al., 2012; Mann et al., 2013)). Additionally, various cooperatives and corporate farms demonstrate high efficiency (Mathijs and Vranken, 2001).

In recent years, the number of non-family farms in Japan has increased as family farms are being discontinued due to difficulties in finding a successor (Hisano et al., 2018). In 2005, the number of corporate farms was 28,000 compared to 1.98 million family farms, but recent statistics show that the former has increased to 33,000, while the latter has decreased to 1.34 million (Ministry of Agriculture Forestry and Fisheries, 2015a). In terms of employment, corporate farms occupy a larger share and employ 121,000 full-time employees (25.3 million man-days in total), whereas family farms employ 100,000 people (17.86 million man-days in total). Furthermore, in recent years, farms are increasing in size; thus, the weight of non-family farms is greater. For example, excluding Hokkaido, where large-scale farms are common, the share of farms with an arable area under management of 10 ha or more has reached an average of $27.0 \%$ throughout the country (Ministry of Agriculture Forestry and Fisheries, 2015a). In terms of the breakdown by organizational form, the proportion occupied by family farms (including those that have been corporatized) is $12.5 \%$, as opposed to $14.5 \%$ for non-family farms.

Non-family farms involved in paddy production in Japan exist mainly in two organizational forms: community farms and joint-stock farms (hereafter, joint farms). Community farms occupy $70 \%$ of the area under paddy cultivation by non-family farms (Suzumura, 2018). Community farms are firms in which the landowners in the rural community invest capital equally and lease their land to the firm. The difference between this and joint farms, described later, is that these are financed by a majority of the rural community members using the regional bonds of the rural community as a foundation. Hence, they have features of a cooperative with community restrictions. The main benefit of this system is the ability to secure sizable farmlands. As a result, not only can efficiency be increased in machinery work but also various forms of cooperation can be obtained from the rural community. Some members are part-time farmers who have non-agricultural income and are considered supportive in unexpected situations (Størdal et al., 2007). On the other hand, because of the conflicting interests of landowners, investors, employees, and managers in a firm, effective decision-making is often unattainable and communication issues may occur (Ando, 1991; Brem and Kim, 2000; Miyatake, 2007).

A joint farm is financed by multiple farmers and managed by pooling their managerial resources. Previous studies have indicated that the scale of multi-family farms is generally larger than that of family farms (Lillywhite and Duffy, 2001; Moreno-Pérez and Lobley, 2015; Moreno-Pérez et al., 2011). In Japan, where nuclear families are the norm, there are more joint farms formed on the basis of sharing machinery as mentioned by Larsén (2010) than those formed on the basis of family relations. By merging with neighboring farmers to establish joint farms, it is possible to secure capital, farmland, and labor, thereby allowing improved utilization rate of machinery through scale expansion. Most of these joint farms have been corporatized, hire employees, and are expanding their scale of operation.

This study examines how differing organizational forms affect operational responses to weather and working conditions. It provides insights for improving the sustainability of emerging occupational options (i.e. regular employment) in non-family farm corporations.

\section{Materials and methods}

In Japan, rice is generally planted during the spring season, irrigated until August, and harvested once a year in autumn. After the 1970s, the use of rice planting machines and combine harvesters expanded. Many large farms that own these machines also perform custom work for smaller farmers. Direct seeding, instead of rice planting, has emerged in recent years but is not widespread. 
Rice harvesting in the busy farming season is done by a combine harvester operated by two or three people, which includes sequential processes from reaping and transport to drying. Because reaping is not possible when morning and evening dew sticks to the rice husks, harvesting is generally done between 10 am and $5 \mathrm{pm}$, on clear days. In addition, because delayed harvesting leads to decreased quality, such as broken kernels, the harvesting period is limited to about one month.

In this research, we selected the plains of Fukui Prefecture, where paddy cultivation is predominant, as a regional case study. The prefecture's annual agricultural production amounts to 40 billion yen ${ }^{1}, 35.4$ billion of which yen is attributed to arable farming and 25 billion yen to rice (Ministry of Agriculture Forestry and Fisheries, 2016). With regard to the area farmed, $90.6 \%$ of the arable land comprises paddy fields, which includes most of the large-scale farms in this region (Ministry of Agriculture Forestry and Fisheries, 2015c). The number of farms by organizational form and scale, and a breakdown of the area in the region, are shown in Table 1. The 44 farms with an area of 50 ha or more (35 of which are non-family farms) occupy 10.4\% of the farming area of the region (8.5\% of which are non-family farms) (Ministry of Agriculture Forestry and Fisheries, 2015b).

The case study was conducted in February 2015 on six large-scale farms holding 50 ha or more by inquiring the prefecture's Agricultural Experimental Center and obtaining the relevant information on the farms examined in this regional case study. Generally, large-scale farms are more profitable in rice cultivation (e.g. Kawasaki, 2010), and working conditions are relatively better (Nanseki et al., 2013; National Chamber of Agriculture, 2011). These farms are suitable for showing future prospects for non-family farms. We used this sampling approach because a detailed organizational structure for farms was not available in public materials. Since the number of large-scale farms in the population itself is small - 12 joint and 23 community farms of 50 ha or more - representative bias is limited. The cases are leading farming corporations in the region and thus appropriate for our study.

For each respective case, the business outlook and actual working conditions during the busy period were surveyed by conducting semi-structured interviews lasting 1.5-2 hours. Securing a sufficient number of samples is difficult but case study method was adopted because information about overworking is sensitive, and managers might not truthfully answer a mail survey. Moreover, interviews are better for understanding the complexities of the organization of workers and how they work.

Table 1. Organizational forms in regional case study, number of farms by scale, and area under farm (Ministry of Agriculture Forestry and Fisheries $2015 \mathrm{a}, \mathrm{b}){ }^{1}$

\begin{tabular}{|c|c|c|c|c|c|c|c|c|}
\hline & \multicolumn{4}{|c|}{ Number of farms } & \multicolumn{4}{|c|}{ Area under farm (ha) } \\
\hline & Total & $<10$ ha & 10-50 ha & $>50$ ha & Total & $<\mathbf{1 0}$ ha & $10-50$ ha & $>50$ ha \\
\hline \multirow[t]{2}{*}{ Total for Fukui Prefecture } & 15,268 & 14,818 & 406 & 44 & 30,658 & 18,701 & 8,783 & 3,174 \\
\hline & $100.0 \%$ & $97.1 \%$ & $2.7 \%$ & $0.3 \%$ & $100.0 \%$ & $61.0 \%$ & $28.6 \%$ & $10.4 \%$ \\
\hline \multirow[t]{2}{*}{ Family farms } & 14,984 & 14,747 & 228 & 9 & 23,023 & 18,443 & 4,022 & 558 \\
\hline & $98.1 \%$ & $96.6 \%$ & $1.5 \%$ & $0.1 \%$ & $75.1 \%$ & $60.2 \%$ & $13.1 \%$ & $1.8 \%$ \\
\hline \multirow{2}{*}{$\begin{array}{l}\text { Farm corporations } \\
\text { (excl. community farms) }\end{array}$} & 100 & 43 & 45 & 12 & 1,917 & 145 & 1,031 & 741 \\
\hline & $0.7 \%$ & $0.3 \%$ & $0.3 \%$ & $0.1 \%$ & $6.3 \%$ & $0.5 \%$ & $3.4 \%$ & $2.4 \%$ \\
\hline Community farm & 183 & 27 & 133 & 23 & 5,718 & 113 & 3,730 & 1,875 \\
\hline Corporations & $1.2 \%$ & $0.2 \%$ & $0.9 \%$ & $0.2 \%$ & $18.6 \%$ & $0.4 \%$ & $12.2 \%$ & $6.1 \%$ \\
\hline
\end{tabular}

${ }^{1}$ Unincorporated non-family operations (non-statutory groups) are excluded.

\footnotetext{
${ }^{1} 1 \mathrm{USD}=110$ yen approximately.
} 
We collected and detailed daily work records during the busy farming season (i.e. the harvesting season) for two cases - joint and community farms of similar business scale that agreed to provide records - and verified the relation between weather and overworking. A combine harvester cannot be used on days with more than $5 \mathrm{~mm}$ of rainfall and on the day after $15 \mathrm{~mm}$ or more of rainfall (Ministry of Agriculture Forestry and Fisheries, 1987). Therefore, we verified the relation between rainfall and overworking using data from the Automated Meteorological Data Acquisition System (AMEDAS). We defined overworking as work by specific individuals without weekly offs, on the basis of the judgment criteria of other industries (International Labor Organization, 2014).

In addition, because many residents in community farms are engaged as part-time employees with high numerical flexibility, contacting and coordinating with these individuals incurs costs. Specifically, it is necessary to constantly revise the work plan and assign work according to changes in the weather and work progress. Therefore, we verified the flexibility of farms by examining to what extent the preliminary planning of harvesting differed from actual work attendance and what kind of coordination was carried out in response to the weather.

An overview of the six farms in this case study is shown in Table 2. Among these farms, J1-J4 are joint farms shared by several farmers. $\mathrm{C} 1$ and $\mathrm{C} 2$ are community farms primarily shared by residential farmers of rural communities, who rent and work at rural community farmlands. These are large rice cultivation farms in the prefecture, which possess 50 ha or more of arable land under their management and exceed a revenue of 50 million yen. Other than rice cultivation, these farms produce barley, soybeans, and buckwheat and undertake harvesting and other custom work. As generally seen in Japanese rice farms of a similar scale, all the farms in this case study own multiple rice planting machines and combine harvesters and drying machines for the drying process, which are used primarily for rice cultivation.

Table 2. The overview of sample farms, $2014 .{ }^{1}$

\begin{tabular}{|c|c|c|c|c|c|c|}
\hline Farm & $\mathbf{J 1}$ & $\mathbf{J} 2$ & $\mathbf{J 3}$ & J4 & C1 & $\mathrm{C2}$ \\
\hline $\begin{array}{l}\text { Year of } \\
\text { incorporation }\end{array}$ & 1989 & 1992 & 1990 & 2009 & 2005 & 2006 \\
\hline $\begin{array}{l}\text { Capital stock / } \\
\text { no. of investors }\end{array}$ & 5.2 mil. yen / 4 & 8 mil. yen / 4 & 13.5 mil. yen / 3 & 9.9 mil. yen / 2 & 17.3 mil. yen / 37 & 9.2 mil. yen / 66 \\
\hline Revenue & 71 mil. yen & 79 mil. yen & 88 mil. yen & $\begin{array}{l}100 \text { mil. yen, of } \\
\text { which } 39 \text { mil. } \\
\text { yen is attributed } \\
\text { to agriculture }\end{array}$ & 75 mil. yen & 140 mil. yen \\
\hline $\begin{array}{l}\text { Area of arable } \\
\text { land under } \\
\text { management }\end{array}$ & 85 ha & 116 ha & 115 ha & 76 ha & 57 ha & 102 ha \\
\hline $\begin{array}{l}\text { Planting } \\
\text { composition }\end{array}$ & $\begin{array}{l}\text { rice paddy } 54 \text { ha, } \\
\text { wheat } 33 \text { ha, } \\
\text { vegetables } 0.1 \text { ha }\end{array}$ & $\begin{array}{l}\text { rice paddy } 103 \text { ha, } \\
\text { buckwheat } 1 \text { ha, } \\
\text { vegetables } 0.5 \text { ha, } \\
\text { canora } 0.5 \text { ha }\end{array}$ & $\begin{array}{l}\text { rice paddy } 70 \\
\text { ha, feed } 37 \text { ha, } \\
\text { vegetables } 1.3 \text { ha }\end{array}$ & $\begin{array}{l}\text { rice paddy } 69 \text { ha, } \\
\text { wheat } 3.3 \text { ha, } \\
\text { soybeans } 7 \text { ha, } \\
\text { buckwheat } 20.5 \text { ha }\end{array}$ & $\begin{array}{l}\text { rice paddy } 40 \text { ha, } \\
\text { wheat } 17.4 \text { ha, } \\
\text { soybeans } 14.2 \text { ha, } \\
\text { buckwheat } 3.3 \text { ha }\end{array}$ & $\begin{array}{l}\text { rice paddy } 70 \text { ha, } \\
\text { wheat } 31 \text { ha, } \\
\text { soybeans } 17.4 \text { ha, } \\
\text { buckwheat } 14.3 \text { ha }\end{array}$ \\
\hline
\end{tabular}




\section{Results}

\subsection{Work during the busy farming season and the state of labor management}

Work and holiday management at the farms in this case study during the busy farming season is shown on Table 3. Joint farms (J1-J4) are managed by 2-5 board members who are mostly paid a monthly wage. Fulltime employees are on a monthly wage system except for those at $\mathrm{J} 1$, and additional part-time employees are often hired during the busy farming season. Excluding J2, during the harvest season, employees assemble at 7:30 am or 8 am for a meeting before starting work. In J2, due to a heavy workload, employees work from 5:30 am ( $3 \mathrm{am}$ for the operator of the drying process) to $5 \mathrm{pm}$, a total of 11.5-14 hours. In addition, the J1 manager works overtime for about an hour every day to keep work records. Employees of J3 and J4 work overtime for one hour and three hours, respectively. Employees of J2 and J4 work much more than the standard 40 hours a week. Such overtime is prevalent for full-time employees hired on a monthly wage. In terms of holiday management, excluding J1, regular holidays are not fixed, and employees take turns leaving one day a week. In addition, J1 also changes the regular Sunday holidays into working days in the event of continuous rain.

Community farms $(\mathrm{C} 1, \mathrm{C} 2)$ are founded on the collective consensus of a community; thus, compared to joint farms, community farms tend to have more board members and employees. Wages for both farms are paid hourly, and the majority of the employees either earn their non-farm income or are retired. These two farms adopt a group system, with each group comprising about seven people, wherein members report to their group leaders. The distinct feature of both these community farms is their prior planning at the beginning of the work season for groups and workers responsible for each day in the season, with work being done according to these plans. During the harvest period at $\mathrm{C} 1$, a board member determines the feasibility of work at 8 am every day and contacts the groups via telephone or e-mail if work is unfeasible. At C2, the farming manager (a board member) determines feasibility at 6 am and contacts the groups by telephone. At either farm, work finishes between 5-5:30 pm, with no overtime. After the completion of the work, the board member writes a daily report at $\mathrm{C} 1$, which is done by the group leader at $\mathrm{C} 2$. Non-operation days are not fixed - not even weekends - and when it rains, the work roster is canceled rather than rescheduled. Therefore, employees can anticipate their working days according to the roster. If it is necessary for a $\mathrm{C} 1$ employee to be absent, that employee must find a substitute and inform the group leader. At C2, employee absence is announced on a chalkboard four or five days in advance, and board members will find a substitute. Thus, the involvement of many part-time employees allows for flexibility and less overwork, although there are coordination costs arising from work cancelation due to rainy weather or employee absence for personal reasons.

\subsection{Flexibility and overworking in response to weather change}

\section{- State of overworking}

Next, we clarify the relation between the weather, work flexibility, and overworking in detail, on the basis of the work reports at $\mathrm{J} 1$ and $\mathrm{C} 1$. Table 4 summarizes workdays, holidays, and overworking by the type of employees in attendance during the busy farming season.

In the joint farm, $\mathrm{J} 1$, three main employees who present at work the most work an average of 5.7 days per week (1.5 days in weekends). These three have less than two days off per week on an average. In addition, during the harvest period, four employees had to work consecutive weeks with no days off.

On the other hand, at $\mathrm{C} 1$ - the community farm - only one person worked more than the average of five days per week, with 19 employees working less than one day per week. These one-shot employees comprised $15 \%$ of the total time worked. However, one employee had less than two days off per week, and three employees had to work for some weeks with no days off. By having many part-time employees, the load on each employee decreases; however, some are overworked to some extent. 
Table 3. Work and holiday management during busy farming season in case farms. ${ }^{1,2}$

\begin{tabular}{|c|c|c|c|c|c|c|}
\hline Farms & J1 & $\mathbf{J} 2$ & J3 & J4 & C1 & $\mathrm{C2}$ \\
\hline $\begin{array}{l}\text { No. of managers } \\
\text { and board members }\end{array}$ & $4(\mathrm{M})$ & $4(\mathrm{M})$ & $\begin{array}{l}4 \text { full-time }(\mathrm{M}), 1 \\
\text { part-time }(\mathrm{H})\end{array}$ & $\begin{array}{l}\text { Of } 2(\mathrm{M}), 1 \text { is } \\
\text { in division for } \\
\text { restaurant }\end{array}$ & $\begin{array}{l}3 \text { full-time, } \\
9 \text { part-time }\end{array}$ & $\begin{array}{l}4 \text { full-time, } \\
8 \text { part-time }\end{array}$ \\
\hline $\begin{array}{l}\text { Organization and } \\
\text { no. of employees }\end{array}$ & $\begin{array}{l}10 \text { full-time }(\mathrm{H}) \text {, } \\
\text { of which } 1 \text { does } \\
\text { office work; } \\
2 \text { part-time }(\mathrm{H})\end{array}$ & 4 full-time $(\mathrm{M})$ & $\begin{array}{l}4 \text { full-time }(\mathrm{M}) \text {, } \\
\text { of which } 1 \text { does } \\
\text { office work; } \\
3 \text { part-time }(\mathrm{H})\end{array}$ & $\begin{array}{l}8 \text { full-time }(\mathrm{M}) \text {, } \\
2 \text { part-time } \\
(\mathrm{H})(\text { except } \\
\text { restaurant } \\
\text { division) }\end{array}$ & $\begin{array}{l}32 \text { contributory } \\
\text { employees } \\
(\mathrm{H}), \text { of which } \\
12 \text { also serve } \\
\text { as executive } \\
\text { members }\end{array}$ & $\begin{array}{l}64 \text { contributory } \\
\text { employees } \\
\text { (H) of which } \\
12 \text { also serve } \\
\text { as executive } \\
\text { members; } \\
2 \text { part-time }(\mathrm{H})\end{array}$ \\
\hline Constant overtime & Yes & Yes & Yes & Yes & & \\
\hline $\begin{array}{l}\text { Late night and early } \\
\text { morning work }^{3}\end{array}$ & & Yes & & & & \\
\hline $\begin{array}{l}\text { General schedule } \\
\text { during busy } \\
\text { farming season }\end{array}$ & $\begin{array}{l}\text { Assemble for } \\
\text { meeting at } 8 \\
\text { am. Work is } \\
\text { done around } \\
6 \mathrm{pm} \text {. Then, } \\
\text { managers take } \\
\text { about an hour for } \\
\text { record keeping. } \\
\text { Communication } \\
\text { done by e-mail } \\
\text { and telephone. }\end{array}$ & $\begin{array}{l}\text { Assemble at } \\
\text { 5:30 am, dusting } \\
\text { and cleaning } \\
\text { done during } \\
\text { the discussion. } \\
\text { Bagging is done } \\
\text { at } 5 \text { pm, after } \\
\text { which work is } \\
\text { completed. } \\
\text { One worker for } \\
\text { drying machine } \\
\text { works from } 3 \\
\text { am. }\end{array}$ & $\begin{array}{l}\text { Assemble at 7:30 } \\
\text { am for meeting. } \\
\text { Work ends at } 5 \\
\text { pm. One-hour } \\
\text { overtime daily, } \\
\text { on average. } \\
\text { Work attendance } \\
\text { is managed by } \\
\text { time cards. } \\
\text { Daily work is } \\
\text { recorded on PCs } \\
\text { by employees. }\end{array}$ & $\begin{array}{l}\text { Assemble } \\
\text { at } 8 \text { am. } \\
\text { Work ends at } \\
5 \text { pm. } \\
3 \text { hours overtime } \\
\text { daily. }\end{array}$ & $\begin{array}{l}\text { Executive } \\
\text { members take } \\
\text { turns for leading } \\
\text { the assembly at } \\
8 \text { am to decide } \\
\text { work feasibility. } \\
\text { General meeting } \\
\text { at } 8 \text { am, with } \\
\text { harvesting and } \\
\text { drying starting } \\
\text { at } 11 \text { am, until } \\
\text { completed. Work } \\
\text { is done by } 5 \\
\text { pm. Executive } \\
\text { member records } \\
\text { a work log. }\end{array}$ & $\begin{array}{l}\text { Farming director } \\
\text { decides work } \\
\text { feasibility at } 6 \\
\text { am and contacts } \\
\text { employees. } \\
\text { Group leader } \\
\text { sets up to begin } \\
\text { work. Harvesting } \\
\text { begins at } 11 \text { am, } \\
\text { and employees } \\
\text { finish work at } \\
5: 30 \text { pm. Group } \\
\text { leader records in } \\
\text { work log. }\end{array}$ \\
\hline No. set holidays & Yes & Yes & Yes & Yes & Yes & Yes \\
\hline $\begin{array}{l}\text { Holiday } \\
\text { management during } \\
\text { busy farming } \\
\text { season }\end{array}$ & $\begin{array}{l}\text { Sundays off. } \\
\text { When it rains } \\
\text { for several } \\
\text { days during the } \\
\text { weekdays, those } \\
\text { days are taken } \\
\text { off to work on } \\
\text { Sunday instead. }\end{array}$ & $\begin{array}{l}\text { No set holidays, } \\
\text { with employees } \\
\text { taking turns to } \\
\text { take one day off } \\
\text { per week. }\end{array}$ & $\begin{array}{l}\text { No set holidays, } \\
\text { with employees } \\
\text { taking turns to } \\
\text { take one day off } \\
\text { per week. }\end{array}$ & $\begin{array}{l}\text { Employees take } \\
\text { turns to take one } \\
\text { day off per week. }\end{array}$ & $\begin{array}{l}\text { Work planning } \\
\text { done in advance, } \\
\text { with a work plan } \\
\text { created for each } \\
\text { employee. No set } \\
\text { holidays, with } \\
\text { no work on rainy } \\
\text { days. }\end{array}$ & $\begin{array}{l}\text { Work planning } \\
\text { done in advance, } \\
\text { with a work plan } \\
\text { created for each } \\
\text { employee. No set } \\
\text { holidays, with } \\
\text { no work on rainy } \\
\text { days. }\end{array}$ \\
\hline
\end{tabular}

${ }^{1} \mathrm{~J} 1-\mathrm{J} 4$ = joint farms; C1-C2 = community farms.

2 ' $M$ ' denotes monthly salary while ' $H$ ' denotes hourly wages. Board members in community farms receive hourly wages as employees and a very minimal amount (a few tens of thousands of yen) annually as executive compensation.

${ }^{3}$ Late night and early morning work spans 10:00 pm to 5:00 am under Japan's Labor Standards Act. 
Table 4. Employee engagement during busy farming season. ${ }^{1}$

\begin{tabular}{|c|c|c|c|c|c|c|c|c|}
\hline \multicolumn{9}{|l|}{$\mathbf{J 1}$} \\
\hline \multicolumn{4}{|c|}{ Type of employees in attendance } & \multicolumn{3}{|c|}{ Work and days off per week } & \multicolumn{2}{|l|}{ Overwork } \\
\hline $\begin{array}{l}\text { Attendance } \\
\text { per week }\end{array}$ & $\begin{array}{l}\text { No. of } \\
\text { employees }\end{array}$ & Total weeks & $\%$ & $\begin{array}{l}\text { Average } \\
\text { working } \\
\text { days }\end{array}$ & $\begin{array}{l}\text { of which are } \\
\text { weekends }\end{array}$ & $\begin{array}{l}\text { Average days } \\
\text { off during } \\
\text { weekdays }\end{array}$ & $\begin{array}{l}\text { Employees } \\
\text { with less } \\
\text { than two } \\
\text { days off per } \\
\text { week } \\
\end{array}$ & $\begin{array}{l}\text { Employees } \\
\text { with no days } \\
\text { off }\end{array}$ \\
\hline $5+$ days & 3 & 17.0 & 37 & 5.7 & 1.5 & 0.6 & 3 & 3 \\
\hline 3-5 days & 4 & 15.9 & 34 & 4.0 & 0.9 & 1.7 & 0 & 1 \\
\hline 1-2 days & 6 & 13.3 & 22 & 2.2 & 0.6 & 3.2 & 0 & 0 \\
\hline$<1$ day & 1 & 0.0 & 0 & 0.0 & 0.0 & 4.8 & 0 & 0 \\
\hline All employees & 14 & 46.1 & 100 & 3.3 & 0.8 & 1.4 & 3 & 4 \\
\hline \multicolumn{9}{|l|}{ C1 } \\
\hline \multicolumn{4}{|c|}{ Type of employees in attendance } & \multicolumn{3}{|c|}{ Work and day off per week } & \multicolumn{2}{|l|}{ Overwork } \\
\hline $\begin{array}{l}\text { Attendance } \\
\text { per week }\end{array}$ & $\begin{array}{l}\text { No. of } \\
\text { employees }\end{array}$ & Total weeks & $\%$ & $\begin{array}{l}\text { Average days } \\
\text { of work }\end{array}$ & $\begin{array}{l}\text { of which are } \\
\text { weekends }\end{array}$ & $\begin{array}{l}\text { Average } \\
\text { weekdays off }\end{array}$ & $\begin{array}{l}\text { Employees } \\
\text { less than two } \\
\text { days off per } \\
\text { week }\end{array}$ & $\begin{array}{l}\text { Employees } \\
\text { with no day } \\
\text { off }\end{array}$ \\
\hline $5+$ days & 1 & 6.0 & 16 & 6.0 & 2.0 & 0.5 & 1 & 1 \\
\hline 3-5 days & 3 & 11.8 & 31 & 3.9 & 0.7 & 1.3 & 0 & 2 \\
\hline 1-2 days & 10 & 14.5 & 38 & 1.5 & 0.9 & 4.0 & 0 & 0 \\
\hline$<1$ day & 19 & 5.5 & 15 & 0.3 & 0.2 & 4.4 & 0 & 0 \\
\hline All employees & 33 & 37.8 & 100 & 1.1 & 0.5 & 3.9 & 1 & 3 \\
\hline
\end{tabular}

${ }^{1}$ Compiled from daily work reports from each farm (year 2014, rice harvesting period).

\section{- Flexibility and overworking in response to the weather}

Table 5 shows the number of workers per day during the harvest period, subtotaled by days when work is feasible or unfeasible. Employees with no days off in the week prior to their workday are counted as ones with no days off. The number of workers for $\mathrm{J} 1$ was 7.1 on feasible days and 5.0 on unfeasible days, indicating no significant difference between operational feasibilities. On the other hand, at C1, there were 6.6 workers on feasible days and significantly less (less than 1\%) on unfeasible days (2.4 employees). In other words, $\mathrm{C} 1$, which uses many part-time workers, is more flexible when responding to changes in the weather. When examining employees with no days off, J1 showed a higher average of $17 \%$ as opposed to $13 \%$ at $\mathrm{C} 1$. J1 stood out with a larger number of employees with no days off due to the amount of work on feasible days.

Table 5. Number of workers during busy farming period on feasible days and infeasible days.

\begin{tabular}{|c|c|c|c|}
\hline $\mathbf{J 1}$ & Number of days & Workers per day & Workers with no days off $(\%)$ \\
\hline Days when work was feasible & 21 & \multirow{2}{*}{ n.s. } & $1.2(17)$ \\
\hline Days when work was unfeasible & 7 & & $0.6(13)$ \\
\hline All days & 28 & 6.6 & $1.1(17)$ \\
\hline C1 & Number of days & Workers per day & Workers with no days off $(\%)$ \\
\hline Days when work was feasible & 20 & \multirow{2}{*}{\}$* *$} & $0.8(12)$ \\
\hline Days when work was unfeasible & 5 & & $0.5(20)$ \\
\hline All days & 25 & 5.8 & $0.7(13)$ \\
\hline
\end{tabular}

$1 * *$ difference between both numbers is significantly less than $1 \%$. 
Figure 2 shows the relationship between the number of workers and overworking, as well as daily weather conditions. At J1, 11 days after the start of the harvest, four full-time employees had intensively overworked for about one week. This outcome was due to continual rain around the start of harvest, making work unfeasible, with core members forgoing days off to make up for delayed work. On the other hand, C1 was also impacted by rain for the first half of the harvest period. Because many workers were available to switch with others, the ratio of overworking was much lower, with one or two core members working overtime. According to daily work reports, those core employees were primarily responsible for post-harvest drying, residual disposal, inspections, and shipment.

\section{- Limitations on numerical flexibility}

At the community farm, $\mathrm{C} 1$, many community residents work as part-time employees, and a coordination in their work schedules in the face of changes in the weather is required to achieve numerical flexibility. This situation can be explored on the basis of daily work reports.

This community farm plans workdays and tasks for each of the 33 employees prior to the beginning of each work season. Work is done in accordance with this plan, but on days made unfeasible by weather, these planned workdays get canceled. In addition, unforeseen changes caused by an employee's inability to work due to health or personal schedule require unplanned work by other employees (Table 6). The results of the compiled daily work reports show that workers needed to be contacted to coordinate schedules for work day cancelations, averaging to 0.3 days of cancelation per week per person for a total of 10 times per week, and, for unplanned work, averaging to 0.4 days per person for a total of 13 times per week.

A

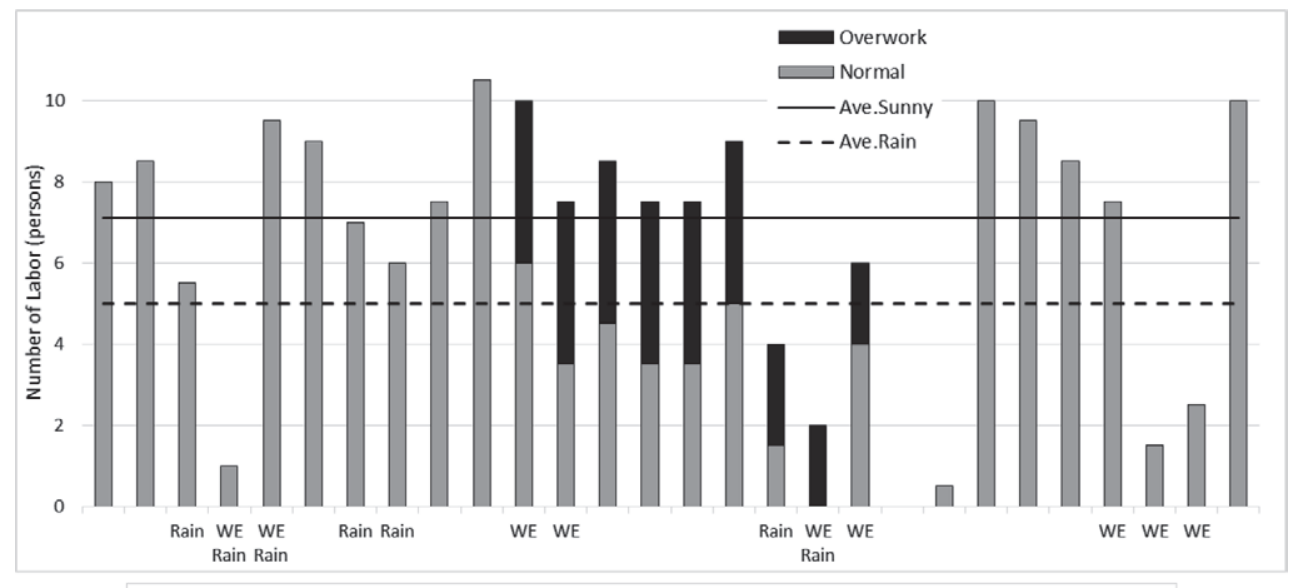

$\mathrm{B}$

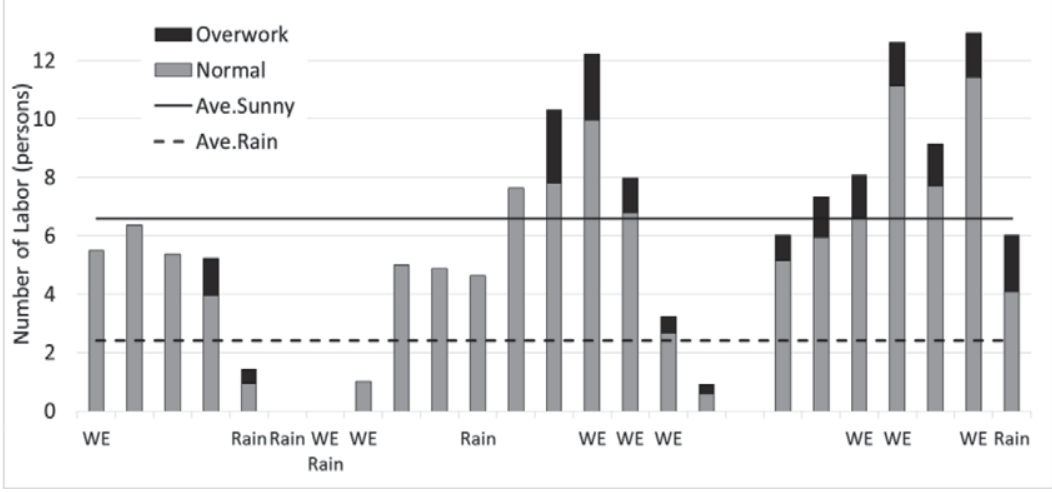

Figure 2. Relationship between number of workers and weather during the busy farming period. Rain indicates days on which work was unfeasible. 'WE' indicates weekends and holidays. Employees with no days off in the week prior to their workday are counted as 'overwork.' $\mathrm{A}=\mathrm{J} 1 ; \mathrm{B}=\mathrm{C} 1$. 
Table 6. Cancelation and unplanned work in $\mathrm{C} 1$ community farm.

\begin{tabular}{|c|c|c|c|c|}
\hline \multirow{2}{*}{$\begin{array}{l}\text { Type of employee in } \\
\text { attendance per week }\end{array}$} & \multicolumn{2}{|c|}{ Cancelations (days/week/person) } & \multicolumn{2}{|c|}{ Unplanned work (days/week/person) } \\
\hline & All days & Weekends & All days & Weekends \\
\hline$>5$ days ${ }^{1}$ & - & - & - & - \\
\hline 3-5 days & 0.8 & 0.4 & 2.4 & 0.4 \\
\hline 1-2 days & 0.4 & 0.2 & 0.5 & 0.1 \\
\hline$<1$ day & 0.2 & 0.2 & 0.0 & 0.0 \\
\hline Average & 0.3 & 0.2 & 0.4 & 0.1 \\
\hline
\end{tabular}

${ }^{1}$ One person who worked more than five days was excluded because the plans for drying and coordination were not listed.

Workday cancelations arise regardless of employee work-frequency. In contrast, this is primarily compensated by full-time core members. Three employees who worked 3-5 days per week had an average of 2.4 days per week of unplanned work, while 19 employees who worked less than one day per week did not engage in unplanned work. Therefore, at community farms, having many part-time employees does not flexibly contribute to unplanned work, but rather leads to rising costs for coordinating schedules.

A comparison of work efficiency demonstrates that a joint farm is more efficient in these two cases. Work efficiency per employee is $0.33 \mathrm{ha}$ /day for $\mathrm{J} 1$ and $0.25 \mathrm{ha}$ /day for $\mathrm{C} 1$. In addition, labor costs for harvesting are $35,000 \mathrm{yen} / \mathrm{ha}$ for $\mathrm{J} 1$ and $48,000 \mathrm{yen} / \mathrm{ha}$ for $\mathrm{C} 1$. Community farms involve more part-time workers, which may result in more wasted time.

\section{Discussion}

This paper aimed to examine the level of employee flexibility for weather conditions at non-family farms during the busy farming season, as well as how much overworking is required.

Among labor management practices, our case study first demonstrates that overtime is typical in joint farms during the busy farming period, with the burden being borne particularly by full-time core members. Giving the profound concern about weather uncertainty (Caicong et al., 2017; Kearney et al., 2014; Logstein, 2016; Truchot and Andela, 2018), joint farms enjoy flexible responses to such improbability. However, farm managers in joint farms recognize flexible labor as overtime work, giving family farms that can rely on family members the advantage (Glover and Reay, 2015). In community farms, in contrast, many community residents can fill in for work, allowing tasks to be completed on time even during the busy farming period. In other words, the workload is shared by several residents and reduces in terms of each worker. Although worker-controlled corporations (community farms) are theoretically inefficient (Carter, 1984; Schmitt, 1991), they respond effectively to weather via the numerical flexibility (Atkinson, 1984) offered by non-regular workers. Accordingly, community farms (hybrid governance structures) are more preferable in terms of less overtime than joint farms and family farms with regard to the governance structure (Williamson, 1979).

Second, the study demonstrated that, for non-family farms, flexibly setting offs for employees allows for timely harvesting during the busy farming season. Of the six cases examined herein, only one joint farm sets specific holidays, and even that farm switches some holidays to workdays due to the weather. Holiday scheduling differs between organizational forms with regard to workers. Joint farms give employees days off by turns, whereas community farms set fixed attendance schedules and workers obtain holiday on infeasible days. Given the industry-wide harsh working conditions (Dumont and Baret, 2017; Gosetti, 2017; Kunitake, 2016; Leschak, 2008), previous studies indicated the scarcity of farms setting holidays (National Chamber of Agriculture, 2010; Winter et al., 2016). Community farms avoid such situations through the collaboration of households enabled by sources of non-agricultural income (Størdal et al., 2007). 
Notably, work sharing limits specialization of labor and constrains farm sizes (Allen and Lueck, 1998). This finding accords with empirical studies that address the smaller economies of scale in community versus joint farms (Yagi and Hayashi, in press). Further decline in rural population may erase supportive households and require specialization of labor (Ministry of Agriculture Forestry and Fisheries, 2015a).

Third, and most importantly, a closer examination of these two cases shows that certain members overwork more in both organizations. Even when the amount of work changed due to weather, only a small percentage of the work was covered by part-time employees, and the majority of the work was handled by full-time employees. Plausible reasons for this outcome are as follows. First, firms view monthly salaries for regular employees as sunk costs and consequently neglect the welfare of those employees. A similar reasoning was explored for family farms in which overwork through the sacrifices of unpaid family members allows for flexibility (Glover and Reay, 2015). Thus, solving this problem requires improvements in working conditions including those in family farms. Second, it is difficult to improve the skill level of part-time employees, and they cannot be put in charge of many types of tasks. This fact is consistent with the idea that when faced with uncertainty, not only numerical flexibility by having part-time employees but also functional flexibility by having full-time employees is required (Atkinson, 1984). Third, a specific issue for organizational farms with many part-time employees is the high cost of communicating and coordinating with them. This is consistent with existing research, which shows that complexity in organizational structures leads to a decrease in efficiency (Campbell and Dinar, 1993) and an increase in bureaucratic costs (Kleinknecht et al., 2016).

Our conclusions rely on several conditions in addition to limited statistical verification due to the nature of the case study. First, disparities in meteorological and operational conditions should be taken into consideration. Uncertainty due to meteorological conditions is widespread in agriculture (Kearney et al., 2014; Logstein, 2016; Truchot and Andela, 2018). In particular, work delays caused by rain stand out in grain production. In areas with less machinery, the mechanisms causing overwork are considered different. At the same time, the automation of rice cultivation is rapidly advancing in countries such as China (Liu et al., 2014; Zhang et al., 2017) and India (Nirmala and Muthuraman, 2009). It is rather likely that as the demand for improvement in working conditions increases, issues with machinery work in relation to weather uncertainty will become more apparent. Second, disparities in labor market conditions should be considered. For example, in England, farm managers take more holidays at larger farms (Winter et al., 2016). This shows that the burden on regular employees is lessened at farms where it is possible to use low-wage workers such as migrants. In other words, low-wage workers play a certain role in increasing the competitiveness of agriculture (e.g. Darpeix et al., 2014; Krissman, 1995). However, rice farmers in Japan have limited opportunities to hire low-wage migrant workers (Suzumura, 2018), which makes improving numerical flexibility difficult, and thus, farms respond 'functionally' by compelling full-time employees to overwork. Therefore, if working conditions for migrant workers improve around the world, there may be a possibility of seriously addressing the issue of overworking regular employees.

With regard to the effective technological developments and strategies taken by individual farms, improvements in the accuracy of weather forecasts appear to be effective. If the accuracy of long-term forecasts improves, securing the required workers in advance becomes feasible (Jones et al., 2000). In addition, the development of machinery that can be used in rain as well as fields that feature improved water drainage, where equipment can be readily used, (De Toro and Hansson, 2004; Tabuchi, 2004) could also be effective. Diversification of products and businesses adapting to increased demand during rainy season is also considered an effective strategy for farms. In a year with heavy rains, if the weather can be forecast, farms may be able to reduce the area available for rice cultivation, switching their infrastructure and human resources to growing vegetables, which are expected to have considerable demand during the rainy period. Alternatively, if machinery and employees are transferable (e.g. Zhang et al., 2017), farms in regions experiencing heavy rain could lease harvesting equipment and personnel to regions with little rain.

Policy measures include the application of Good Agricultural Practice standards and tighter regulations for overworking (Tey et al., 2016). Regulations on working conditions in agriculture have been sidelined 
throughout the world despite the importance of reducing overworking, including at family farms (International Labor Organization, 2015, etc.). Alternatively, it has been shown, both theoretically and empirically, that with the understanding of taxpayers, the implementation of direct payments to farms reduces labor pressure (Caraveli, 2000; Hecht et al., 2016).

\section{Conclusions}

Small-scale family farms are generally considered the preferable form of agriculture. However, just as in other industries, many young farm workers prefer to work as salaried workers, which has drawn attention to non-family farms as providers of employment opportunities. However, in agriculture, where there is a strong need to flexibly respond to weather, there is no clarity as to whether workplaces without overworking can exist. This paper clarified the relation between weather, labor management, and overworking during the busy farming season, at joint farms and community farms, both of which are representatives of non-family farms in Japan. Our observations encompass leading large-scale farm corporations in the region with better operational conditions, but their working conditions are not necessarily preferable.

In conclusion, the results of our analysis show first that even in non-family farms work coordination flexibly accounts for weather, and systems that allow for harvesting at appropriate times are in place. A closer analysis of work records shows that, in either organizational structure, specific members need to overwork. Reasons for this include issues with sunk costs in the form of monthly wages, lack of skills among part-time employees, and the communication costs to coordinate with many part-time employees.

Second, with respect to governance structures, at joint farms where multiple farmers jointly invest, work is done by full-time employees working overtime during the busy farming period. In contrast, at community farms, there are many community residents that take turns in working, which allows work to be done on time. However, even in the latter case, overworking cannot be avoided. Community farms in particular face inefficiencies in coordination costs with many community residents working part-time; however, their working conditions are relatively favorable. The rural population that forms the foundation of community farms also is a concern.

The results obtained from the analysis are based on a comparison under a certain set of conditions - i.e. leading farm corporations in the region. Changes in market and policy conditions will likely lead to different results. Nonetheless, community farms, such as those seen in Japan's rice paddy field production, in which work conditions are kept relatively favorable, are significant examples to compare with paddy field farms in Asia, where small- to medium-sized farms predominate. Lastly, financial flexibilities when hiring employees effectively can be issues for future research.

\section{Acknowledgements}

This study was supported by a grant from JSPS KAKENHI (grant number 15H04555 and 19H03062) and NARO Smart Agriculture Demo. Proj. (Chu D02).

\section{Conflict of interest}

The authors declare no conflict of interest.

\section{References}

Ahn, S.C., J.C. Brada and J.A. Méndez. 2012. Effort, technology and the efficiency of agricultural cooperatives. Journal of Development Studies 48(11): 1601-1616.

Allen, D.W. and D. Lueck. 1998. The nature of the farm. The Journal of Law and Economics 41(2): 343-386. 
Ando, M. 1991. The significance of human relations in group farming. Japanese Journal of Farm Management 29(2): 13-22.

Astika, I.W., K. Sakaki and S. Shibusawa. 1999. Stochastic farm work scheduling algorithm based on short range weather variation (part 1). Journal of the Japanese Society of Agricultural Machinery 61(2): 157-164.

Atkinson, J. 1984. Manpower strategies for flexible organisations. Personnel Management 16(8): 28-31.

Brem, M. and J. Kim. 2000. A status of agricultural producer cooperatives in East European countries. The Journal of The Korean Society of International Agriculture 12(3): 238-256.

Caicong, W., C. Yaping, H. Bingbing and W. Jie. 2017. Classification and evaluation of uncertain influence factors for farm machinery service. International Journal of Agricultural and Biological Engineering 10(6): 164-174. https://doi.org/10.25165/j.ijabe.20171006.3045

Campbell, M.B. and A. Dinar. 1993. Farm organization and resource use. Agribusiness 9(5): 465-480.

Caraveli, H. 2000. A comparative analysis on intensification and extensification in Mediterranean agriculture: dilemmas for LFAs policy. Journal of Rural Studies 16(2): 231-242.

Carney, M. 2005. Corporate governance and competitive advantage in family - controlled firms. Entrepreneurship Theory and Practice 29(3): 249-265. https://doi.org/10.1111/j.1540-6520.2005.00081.x

Carter, M.R. 1984. Resource allocation and use under collective rights and labour management in Peruvian coastal agriculture. The Economic Journal 94: 826-846.

Darpeix, A., C. Bignebat and P. Perrier-Cornet. 2014. Demand for seasonal wage labour in agriculture: what does family farming hide? Journal of Agricultural Economics 65(1): 257-272. https://doi. org/10.1111/1477-9552.12019

De Massis, A., J.H. Chua and J.J. Chrisman. 2008. Factors preventing intra-family succession. Family Business Review 21(2): 183-199.

De Toro, A. and P.-A. Hansson. 2004. Analysis of field machinery performance based on daily soil workability status using discrete event simulation or on average workday probability. Agricultural Systems 79(1): 109-129. https://doi.org/10.1016/S0308-521X(03)00073-8

Dumont, A.M. and P.V. Baret. 2017. Why working conditions are a key issue of sustainability in agriculture? A comparison between agroecological, organic and conventional vegetable systems. Journal of Rural Studies 56: 53-64. https://doi.org/10.1016/j.jrurstud.2017.07.007

Dyllick, T. and H. Kai. 2002. Beyond the business case for corporate sustainability. Business Strategy and the Environment 11(2): 130-141. https://doi.org/10.1002/bse.323

European Commission. 2009. Overview of family-business-relevant issues: research, networks, policy measures and existing studies. EC, Brussels, Belgium.

Fujii, Y., T. Sumita, K. Nakamura and K. Ueda. 2016. Consideration about employee's turn over of the agricultural companies: a case study of the large-scale paddy field farms. Journal of Rural Problems 52(4): 223-228. https://doi.org/10.7310/arfe.52.223

Garner, E. and A.D.L.O. Campos. 2014. Identifying the 'family farm': an informal disucussion of the concepts and definitions. FAO, Rome, Italy.

Glover, J.L. and T. Reay. 2015. Sustaining the family business with minimal financial rewards: how do family farms continue? Family Business Review 28(2): 163-177.

Gorton, M. and S. Davidova. 2004. Farm productivity and efficiency in the CEE applicant countries: a synthesis of results. Agricultural Economics 30(1): 1-16. https://doi.org/10.1111/j.1574-0862.2004.tb00172.x

Gosetti, G. 2017. Sustainable agriculture and quality of working life: analytical perspectives and confirmation from research. Sustainability 9(10): 1-23. https://doi.org/10.3390/su9101749

Graeub, B.E., M.J. Chappell, H. Wittman, S. Ledermann, R.B. Kerr and B. Gemmill-Herren. 2016. The state of family farms in the world. World Development 87: 1-15. https://doi.org/10.1016/j.worlddev.2015.05.012

Grashuis, J. and Y. Su. 2019. A review of the empirical literature on farmer cooperatives: performance, ownership and governance, finance, and member attitude. Annals of Public and Cooperative Economics 90(1): 77-102. https://doi.org/10.1111/apce.12205

Hecht, J., S. Moakes and F. Offermann. 2016. Redistribution of direct payments to permanent grasslands: intended and unintended impacts. EuroChoices 15(3): 25-32. https://doi.org/10.1111/1746-692x.12099 
Hisano, S., M. Akitsu and S.R. McGreevy. 2018. Revitalising rurality under the neoliberal transformation of agriculture: experiences of re-agrarianisation in Japan. Journal of Rural Studies 61: 290-301. https:// doi.org/10.1016/j.jrurstud.2018.01.013

Huang, Z.-H., B. Wu, X.-C. Xu and Q. Liang. 2016. Situation features and governance structure of farmer cooperatives in China: does initial situation matter? The Social Science Journal 53(1): 100-110. https://doi.org/10.1016/j.soscij.2015.09.003

International Labor Organization. 2014. Rules of the game: a brief introduction to international labour standards, $3^{\text {rd }}$ edition. International Labor Organization, Geneva, Switzerland.

International Labor Organization. 2015. Decent and productive work in agriculture: decent work in the rural econoy policy guidance notes. International Labor Organization, Geneva, Switzerland.

Inwood, M.S. and J.S. Sharp. 2012. Farm persistence and adaptation at the rural-urban interface: succession and farm adjustment. Journal of Rural Studies 28(1): 107-117. https://doi.org/10.1016/j.jrurstud.2011.07.005

Jones, J.W., J.W. Hansen, F.S. Royce and C.D. Messina. 2000. Potential benefits of climate forecasting to agriculture. Agriculture, Ecosystems \& Environment 82(1-3): 169-184.

Kawasaki, K. 2010. The costs and benefits of land fragmentation of rice farms in Japan. Australian Journal of Agricultural and Resource Economics 54(4): 509-526.

Kearney, G.D., A.P. Rafferty, L.R. Hendricks, D.L. Allen and R. Tutor-Marcom. 2014. A cross-sectional study of stressors among farmers in Eastern North Carolina. North Carolina Medical Journal 75(6): 384-392. https://doi.org/10.18043/ncm.75.6.384

Kleinknecht, A., Z. Kwee and L. Budyanto. 2016. Rigidities through flexibility: flexible labour and the rise of management bureaucracies. Cambridge Journal of Economics 40(4): 1137-1147. https://doi. org/10.1093/cje/bev056

Kravina, L., A. Falco, N.A. De Carlo, C.S. Andreassen and S. Pallesen. 2013. Workaholism and work engagement in the family: the relationship between parents and children as a risk factor. European Journal of Work and Organizational Psychology 23(6): 875-883. https://doi.org/10.1080/135943 2x.2013.832208

Krissman, F. 1995. Farm labor contractors: the processors of new immigrant labor from Mexico for Californian agribusiness. Agriculture and Human Values 12(4): 18-46.

Kunitake, H. 2016. Agriculture and labor law. The Japanese Journal of Labour Studies 58(10): 69-77.

Larsén, K. 2010. Effects of machinery-sharing arrangements on farm efficiency: evidence from Sweden. Agricultural Economics 41(5): 497-506. https://doi.org/10.1111/j.1574-0862.2010.00461.x

Lee, B.-J., S.-G. Park, K.-B. Min, J.-Y. Min, S.-H. Hwang, J.-H. Leem, H.-C. Kin, S.-H. Jeon, Y.-S. Heo and S.-H. Moon. 2014. The relationship between working condition factors and well-being. Annals of Occupational and Environmental Medicine 26(1): 34.

Leschak, J. 2008. Food prices soar as farmworkers suffer: agribusiness, government and the denial of farm labor rights. Regional Labor Review 11(1): 24-33.

Lillywhite, J.M. and M. Duffy. 2001. Multifamily farms and America's farm structure: a new perspective on an old issue. American Journal of Alternative Agriculture 16(4): 184-190.

Liu, Y., W. Hu, S. Jetté-Nantel and Z. Tian. 2014. The influence of labor price change on agricultural machinery usage in Chinese agriculture. Canadian Journal of Agricultural Economics/Revue Canadienne d'Agroeconomie 62(2): 219-243. https://doi.org/10.1111/cjag.12024

Lobao, L. and C.W. Stofferahn. 2008. The community effects of industrialized farming: social science research and challenges to corporate farming laws. Agriculture and Human Values 25(2): 219-240. https://doi.org/10.1007/s10460-007-9107-8

Logstein, B. 2016. Farm-related concerns and mental health status among Norwegian farmers. Journal of Agromedicine 21(4): 316-326. https://doi.org/10.1080/1059924X.2016.1211055

Mann, S., K. Mittenzwei and F. Hasselmann. 2013. The importance of succession on business growth: a case study of family farms in Switzerland and Norway. Yearbook of Socioeconomics in Agriculture 12: 109-138.

Mathijs, E. and L. Vranken. 2001. Human capital, gender and organisation in transition agriculture: measuring and explaining the technical efficiency of Bulgarian and Hungarian farms. Post-Communist Economies 13(2): 171-187. https://doi.org/10.1080/14631370120052654 
Ministry of Agriculture Forestry and Fisheries. 1987. Technical guidelines for establishing paddy field agriculture. Ministry of Agriculture Forestry and Fisheries, Tokyo,, Japan.

Ministry of Agriculture Forestry and Fisheries. 2015a. Sensus of agriculture forestry and fisheries. Ministry of Agriculture Forestry and Fisheries, Tokyo, Japan.

Ministry of Agriculture Forestry and Fisheries. 2015b. Survey report on community agricultural business. Ministry of Agriculture Forestry and Fisheries, Tokyo, Japan.

Ministry of Agriculture Forestry and Fisheries. 2015c. Arable land area statistics. Ministry of Agriculture Forestry and Fisheries, Tokyo, Japan.

Ministry of Agriculture Forestry and Fisheries. 2016. Agricultural income statistics. Ministry of Agriculture Forestry and Fisheries, Tokyo, Japan

Miyatake, K. 2007. Development of combined community based group farms. Japanese Journal of Farm Management 45(2): 41-45.

Moreno-Pérez, O.M., E. Arnalte-Alegre and D. Ortiz-Miranda. 2011. Breaking down the growth of family farms: a case study of an intensive Mediterranean agriculture. Agricultural Systems 104(6): 500-511. https://doi.org/10.1016/j.agsy.2011.03.007

Moreno-Pérez, O.M. and M. Lobley. 2015. The morphology of multiple household family farms. Sociologia Ruralis 55(2): 125-149. https://doi.org/10.1111/soru.12062

Nanseki, T., S. Takeuchi and Y. Shinozaki. 2013. Business development, ICT use, and personnel training in agricultural corporations: an analysis of a nationwide questionnaire survey. Agricultural Information Research 22(3): 159-173.

National Chamber of Agriculture. 2010. Questionnaire survey results on the condition of employment in agricultural corperations, year 2010. National Chamber of Agriculture, Tokyo, Japan.

National Chamber of Agriculture. 2011. Survey results of the employment in agricultural cooperations, year 2010. National Chamber of Agriculture, Tokyo, Japan.

Nirmala, B. and P. Muthuraman. 2009. Economic and constraint analysis of rice cultivation in Kaithal district of Haryana. Indian Research Journal of Extension Education 9(1): 47-49.

O’ Donoghue, E.J., R.A. Hoppe, D.E. Banker, R. Ebel, K. Fuglie, P. Korb, L. Michael, N. Cynthia and C. Sandretto. 2011. The changing organization of US farming. CreateSpace Independent Publishing Platform, Scotts Valley, CA, USA.

Raynolds, L.T. 2014. Fairtrade, certification, and labor: global and local tensions in improving conditions for agricultural workers. Agriculture and Human Values 31: 499-511. https://doi.org/10.1007/s10460014-9506-6

Schmitt, G. 1991. Why is the agriculture of advanced western economies still organized by family farms? Will this continue to be so in the future? European Review of Agricultural Economics 18(3-4): 443-458.

Sørensen, C.G. and D.D. Bochtis. 2010. Conceptual model of fleet management in agriculture. Biosystems Engineering 105(1): 41-50. https://doi.org/10.1016/j.biosystemseng.2009.09.009

Størdal, S., G. Lien and J. Brian Hardaker. 2007. Perceived risk sources and strategies to cope with risk among forest owners with and without off-property work in Eastern Norway. Scandinavian Journal of Forest Research 22(5): 443-453. https://doi.org/10.1080/02827580701553701

Suess-Reyes, J. and E. Fuetsch. 2016. The future of family farming: a literature review on innovative, sustainable and succession-oriented strategies. Journal of Rural Studies 47: 117-140. https://doi. org/10.1016/j.jrurstud.2016.07.008

Suzumura, G. 2018. Developments and structures in agricultural management and organization management. In: Ministry of Agriculture Forestry and Fisheries (eds.) Analysis report of agricultural and forestry census. Association of Agriculture and Forestry Statistics, Tokyo, Japan, pp. 39-83.

Tabuchi, T. 2004. Improvement of paddy field drainage for mechanization. Paddy and Water Environment 2(1): 5-10. https://doi.org/10.1007/s10333-004-0034-7

Tagiuri, R. and J. Davis. 1996. Bivalent attributes of the family firm. Family Business Review 9(2): 199-208.

Takahashi, D. 2012. Farmland liquidization and transaction costs. The Japanese Journal of Rural Economics 14: 1-19. https://doi.org/10.18480/jjre.14.1 
Tey, Y.S., N. Rajendran, M. Brindal, S.F.A. Sidique, M.N. Shamsudin, A. Radam and A.H.I.A. Hadi. 2016. A review of an international sustainability standard (GlobalGAP) and its local replica (MyGAP). Outlook on Agriculture 45(1): 67-72. https://doi.org/10.5367/oa.2016.0230

Thomson, K.J. and S. Davidova. 2014. Economic aspects of family farming in the European context. In: $88^{\text {th }}$ Annual Conference of the Agricultural Economics Society. April 9-11, 2014. AgroParisTech, Paris, France.

Truchot, D. and M. Andela. 2018. Burnout and hopelessness among farmers: the farmers stressors inventory. Social Psychiatry and Psychiatric Epidemiology 53: 859-886. https://doi.org/10.1007/s00127-0181528-8

Umemoto, M. 1992. Economies of scale in rice production. Bulletin of the Tohoku National Agricultural Experiment Station 84: 113-132.

Whatmore, S., R. Munton, J. Little and T. Marsden. 1987. Towards a typology of farm businesses in contemporary British agriculture. Sociologia Ruralis 27(1): 21-37.

Williamson, O.E. 1979. Transaction-cost economics: the governance of contractual relations. The Journal of Law and Economics 22(2): 233-261.

Williamson, O.E. 2005. The economics of governance. American Economic Review 95(2): 1-18. https://doi. org $/ 10.1257 / 000282805774669880$

Winter, M., M. Lobley, H. Chiswell, K. Howe, T. Wilkinson and P. Wilson. 2016. Is there a future for the small family farm in the UK? Prince's Countryside Fund, London, UK.

Yagi, H. and T. Hayashi. in press. Machinery utilization and management organization in Japanese rice farms: comparison of single-family, multifamily, and community farms. Agribusiness. https://doi. org/10.1002/agr.21656

Zhang, X., J. Yang and R. Thomas. 2017. Mechanization outsourcing clusters and division of labor in Chinese agriculture. China Economic Review 43: 184-195. https://doi.org/10.1016/j.chieco.2017.01.012 